\title{
Biostratigraphy of the Balambo Formation (Lower Cretaceous ) in Jebel Azmer - Sulaimaniya Area, Northeastern Iraq
}

\author{
Tarik S. Abawi \\ Department of Geology \\ College of Science \\ Mosul University
}

\author{
Rund A. Hammoudi \\ Department of Biology \\ College of Science \\ Dohuk University
}

(Received 13/1/2008, Accepted 28/2/2008)

\begin{abstract}
The Balambo Formation (Lower Cretaceous), exposed on Jebel Azmer in Sulaimaniya area northeastern Iraq, consists mainly of well bedded hard limestone. Outcrop of $224 \mathrm{~m}$ of the upper part of the Balambo Formation are well exposed on the surface with a steeply dipping angle. Planktonic foraminifera represent the major microfossil assemblage of the Balambo Formation. Nineteen cosmopolitan planktonic foraminiferal species were recorded from 92 samples. The identified planktonic foraminifera are of typical Tethyan character. Biostratigraphically the exposed part of the Balambo Formation is defined by four zones and two subzones, these are in ascending chronological order: Ticinella primula Zone, Biticinella breggiensis Zone which is divided into two subzones (Ticinella praeticinensis and Rotalipora subticinensis Subzones), Rotalipora ticinensis Zone and Rotalipora appenninica Zone. Accordingly the age of the Balambo Formation in Jebel Azmer is Middle-Late Albian. The presence of a major hiatus at the end of the Rotalipora appenninica Zone delineates the upper boundary of the formation in the studied section.
\end{abstract}

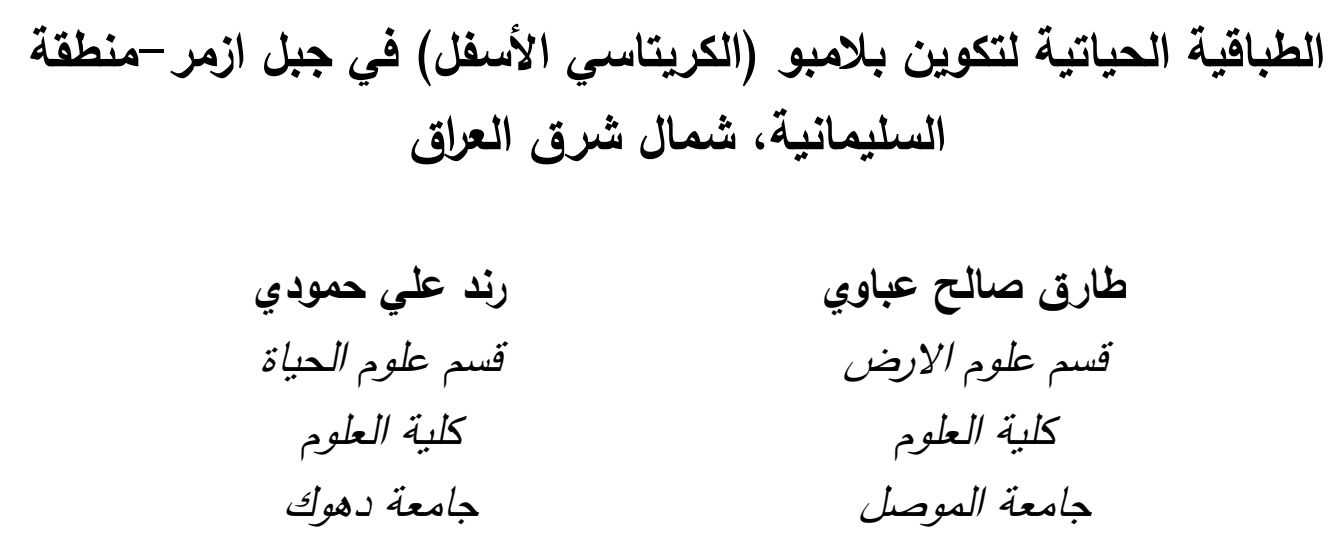

\section{الملخص}

يتألف تكوين بلامبو المنكثف في جبل أزمر في منطقة السليمانية - شمال شرق العراق بشكل أساس

من الحجر الجيري جيد التطبق. يظهر الجزء العلوي من التكوين على السطح بسمك يبلغ ع ب متراً وبزاوية ميل شديدة. تشكل الفورامنيفرا الطافية الجزء الرئيس من حشود المتحجرات الدقيقة ضمن نكوين بلامبو ، إذ سُجّل منها 9 ا نوعاً ذو سمة عالمية من بوه نموذجاً تمت دراستها. حشود الفورامنيفرا الطافية المسجلة في 
الدراسة الحالية تمثل مناطق حوض التيثس. يتمثل الجزء المنكثف من تكوين بلامبو بأربعة أنطقة حياتية

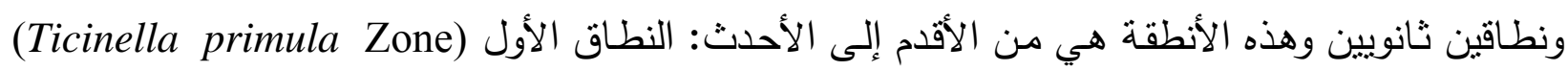
والنطاق الثاني (Biticinella breggiensis Zone) والذي ينقسم الإنى نطاقين ثانين الانيين هما: Ticinella praeticinensis Subzone and Rotalipora subticinensis Subzone

والنطاق الثالث (Rotalipora ticinensis Zone)، والنطاق الرابع(Rotalipora appenninica Zone).

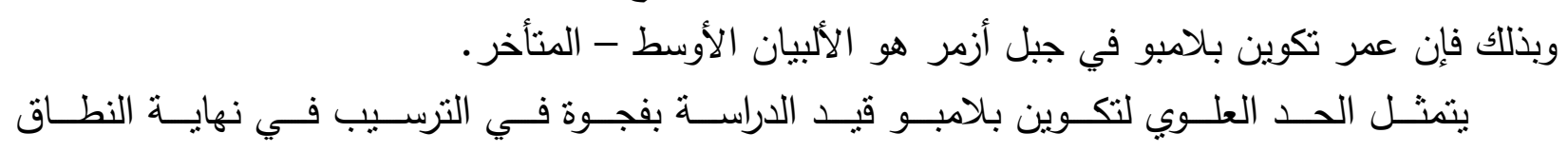
.(Rotalipora appenninica Zone)

\section{INTRODUCTION}

The Balambo Formation was first described by Wetzel in 1947(unpublished report; in Bellen et al., 1959) from the Sirwan Valley, near Halabja, northeastern Iraq.

According to the original description the formation is $762 \mathrm{~m}$. thick and embrace two divisions: Upper division of $503 \mathrm{~m}$; thin bedded globigerinal, passing downwards to radiolarian limestone, grey, weathering white, forming smooth weathered slopes without marked features. Lower division of $259 \mathrm{~m}$.; thin bedded, blue ammonitiferous limestone with intercalations of olive green marls and dark blue shale.

According to Bellen et al. $(1959$, p.51) the age of the Balambo Formation at its type locality is Turonian, at top, to Valanginian, probably Upper Valanginian at the bottom. Bellen et al., (op.cit.) reported very abundant fossil assemblages from the Balambo Formation including diverse foraminiferal and ammonitic faunas as well as occurrence of Radiolaria, Ostracods, Belemnites and Oligostegina.

Buday (1980, p.159) divided the Balambo Formation into two parts based on age and lithology. The Lower Balambo, as a lithological unit, corresponds mostly to the Valanginian-Albian, the uppermost parts reaching into the basal Cenomanian too. The Upper Balambo represents mainly the Cenomanian and Turonian.

Radoicic (1995) studied the Cretaceous biostratigraphy of the Kaolos Area, northeastern Iraq and justified the assignment of the Lower Cretaceous sediments of the studied area to the Balambo Formation. Radoicic (op.cit.) reported rich assemblages of foraminifers and ammonites from the studied sequence and recommended a redefinition of the Balambo Formation and a detailed stratigraphic study.

The present study is based on material from Balambo Formation exposed at Jebel Azmer, about $7 \mathrm{Km}$. northeast of Sulaimaniya, northeastern Iraq (Fig.1). Jebel Azmer lies within the High-Folded Zone of northern Iraq representing a double plunging anticline trending NW-SE.

This paper intends to give an account of the lithology and the planktonic foraminiferal biostratigraphy of the Balambo Formation as exposed at Jebel Azmer, Sulaimaniya area northeastern Iraq.

\section{LITHOLOGY}

Outcrop of $224 \mathrm{~m}$ of the upper part of the Balambo Formation is well exposed on the surface at the core of Jebel Azmer anticline with a steeply dipping angle. Ninety two 
samples were collected from this outcrop at intervals ranging from one to three meters ( Fig.2).

The Balambo Formation in the investigated area is composed lithologically of well bedded hard limestone ranges from light yellow to light grey in colour. Black limestone layers of $20-40 \mathrm{~cm}$ thick rich in organic matter are interbedded randomly with the yellow limestone.

The lower boundary of the Balambo Formation in the studied section is not exposed, while the upper boundary of the formation is delineated by the presence of a major hiatus at the end of the Rotalipora appenninica Zone between the Balambo Formation and the Dokan Formation based on the occurrence of Rotalipora cushmani (Morrow) at the base of Dokan Formation which indicates Middle-Late Cenomanian age (Caron, 1985 and Sliter, 1989, 1992).

Thin sections from the collected samples were studied with regards to their fossils content and microfacies types. Petrographic investigations of the studied material reveals that the sediments of the Balambo Formation are mainly represented by Wackstone to Mudstone Microfacies following the classification of Dunham (1962).

\section{BIOSTRATIGRAPHY}

The thin sections of the Balambo Formation in the study area shows rich microfossils assemblages. The planktonic foraminifera constitutes an important part of the fossil assemblages recorded from the studied section. In addition to the planktonic foraminiferal fauna, the studied material contains the following microfossils remains in varying frequency :

Benthonic foraminifera, Ostracods, sponge spicules, Calcispheres and fragments of dasycladacean green algae. A specific feature of the Balambo Formation in the study area is the occurrence of shallow - water biota (e.g. green algae, sponge spicules, certain benthonic foraminifera).According to Radoicic (1995) these shallow - water biota derived from the Qamchuqa domain situated westward of the basin area.

Nineteen cosmopolitan planktonic foraminiferal species were recorded from 92 samples of the studied material. The identified planktonic foraminifera are of typical Tethyan character, figure 2 shows the stratigraphic distribution of the recorded foraminiferal assemblages.

The planktonic foraminiferal fauna of the studied Balambo Formation shows a rich occurrence of ticinellids. Species belonging to the genera Hedbergella, Heterohelix and Globigerinelloides are common throughout the investigated Balambo sections..

In the determination of the planktonic foraminiferal taxa the authors mainly followed the diagnosis of Caron (1985), Sliter ( 1989, 1992), and Petrizzo and Huber (2006).

The stratigraphic distribution of the planktonic foraminifera recorded from the Balambo Formation permits the recognition of four biozones and two subzones, these are from older at base:

Rotalipora appenninica Zone

Rotalipora ticinensis Zone

Biticinella breggiensis Zone

Rotalipora subticinensis Subzone

Ticinella praeticinensis Subzone

Ticinella primula Zone 
The present zones are correlated with similar ones established by Bolli (1966) general system,Leckie (1984) in Morocco, Caron (1985) in tropical regions, Sliter ( 1989, 1992) in Circum Pacific, and by Petrizzo and Hubber (2006) in western North Atlantic Ocean. The relation of our zones to these zones is shown in figure 3.

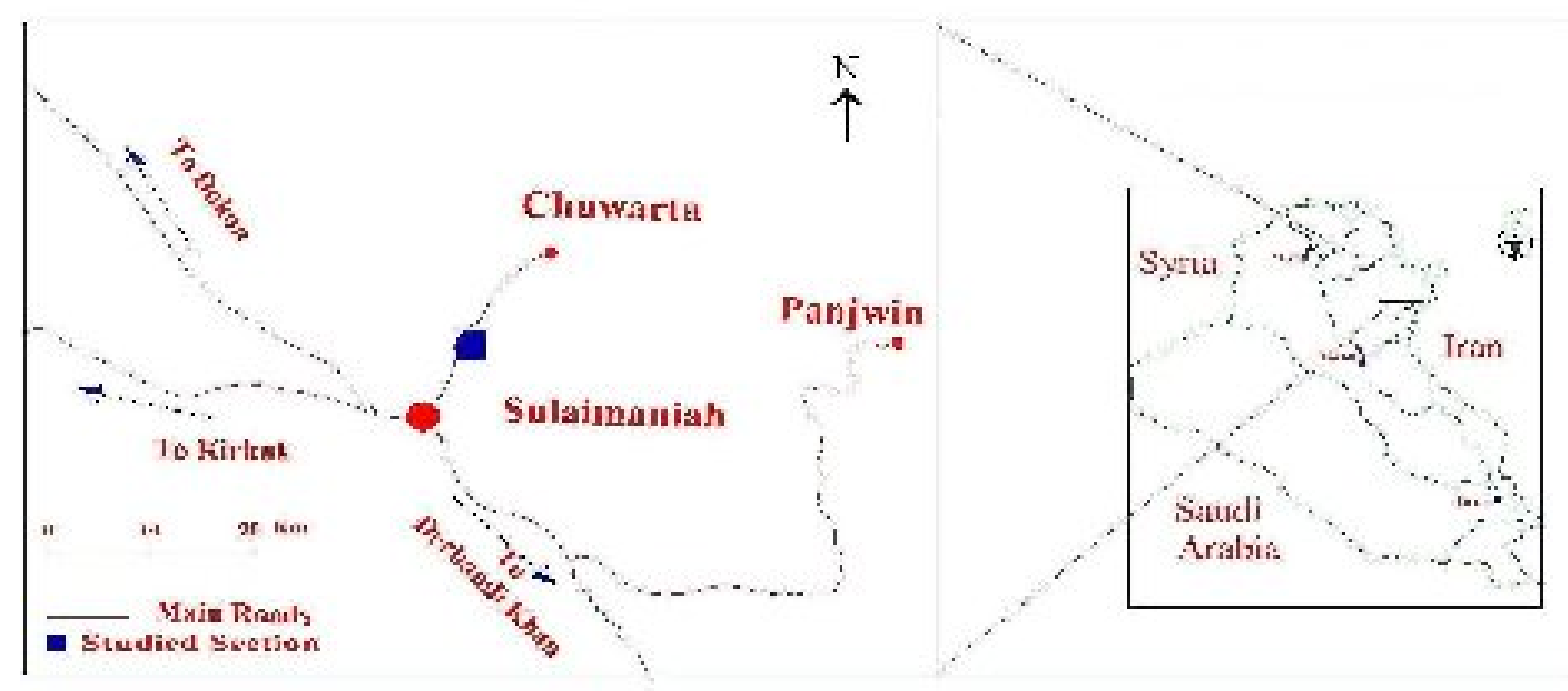

Fig . 1: Location Map

\section{Ticinella primula Interval Zone ( part)}

Definition : Interval from the first occurrence of Ticinella primula Luterbacher to first occurrence of Biticinella breggiensis ( Gandolfi).

Boundaries: The base of the zone is placed at the horizon of the first appearance of the zonal marker, while the upper limit of the zone is marked by the first occurrence of Biticinella breggiensis ( Gandolfi).Only the upper part of this zone is exposed in the study area.

Thickness: $26 \mathrm{~m}$. of the exposed part of the zone.

Correlation: The Ticinella primula Zone is defined by Caron (1985) and Sliter (1989, 1992) to form the Middle Albian. The present zone as it is defined here is correlative to the Ticinella primula Zone of Caron (1985) and Sliter (1992) and so of Middle Albian age.

\section{Biticinella breggiensis Interval Zone}

Definition: Interval from the first occurrence of Biticinella breggiensis ( Gandolfi) to first occurrence of Rotalipora ticinensis ( Gandolfi) .

Boundaries: The base of the zone is marked by the initial appearance of the zonal marker, while the top of the zone is placed at the first occurrence of Rotalipora ticinensis ( Gandolfi).

Thickness: $96.7 \mathrm{~m}$.

Correlation : The present zone as it is defined here is equivalent to the Biticinella breggiensis and the Rotalipora subticinensis Zones of Caron (1985) which are assigned to Late Albian. This zone is also correlative to the Biticinella breggiensis Zone of Sliter $(1989,1992)$ 


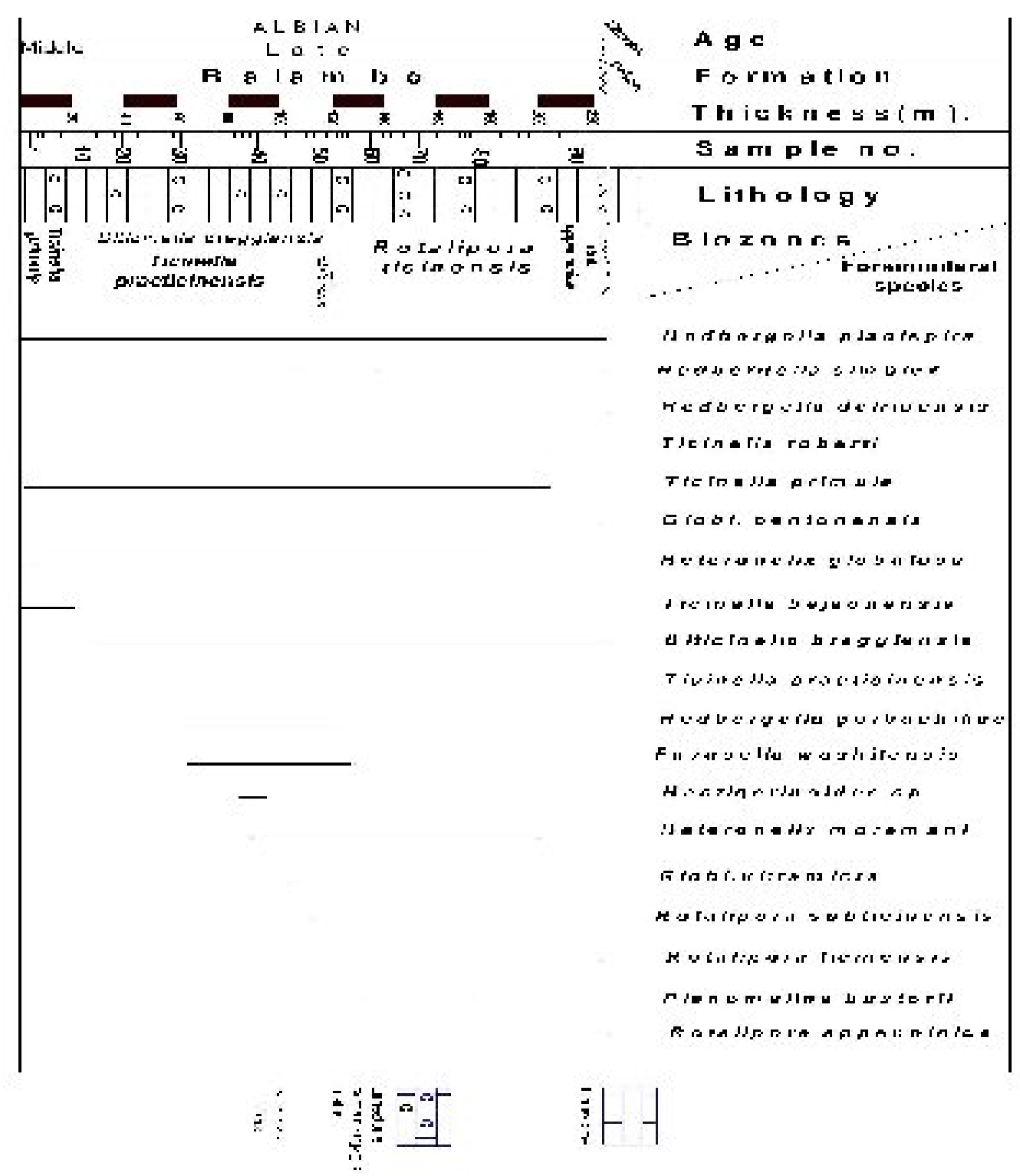

Fig 2: Biostratigraphic Zonation of the Balambo formation, Jebel Azmer, Sulaimaniya Area Northeast Iraq.

The present zone is subdivided into the following two subzones:

\section{1- Ticinella praeticinensis Interval Subzone}

Definition: Interval with Ticinella praeticinensis Sigal prior to the first appearance of Rotalipora subticinensis ( Gandolfi ) .

Boundaries : The base of the subzone is placed at the first appearance of the nominate taxon, while the top of the subzone is marked by the first occurrence of Rotalipora subticinensis ( Gandolfi).

Thickness: $86.7 \mathrm{~m}$.

Correlation: This subzone is correlative to the Ticinella praeticinensis Subzone of Sliter (1989, 1992) and the Biticinella breggiensis Zone of Caron (1985). 


\section{2 - Rotalipora subticinensis Interval Subzone}

Definition: Interval with Rotalipora subticinensis ( Gandolfi ) prior to the first appearance of Rotalipora ticinensis (Gandolfi).

Boundaries: The base of the subzone is placed at the first appearance of the nominate taxon, while the top of the subzone corresponds to the initial appearance of Rotalipora ticinensis ( Gandolfi).

Thickness: $10 \mathrm{~m}$.

Correlation : This subzone is correlative to the Rotalipora subticinensis Subzone of Sliter $(1989,1992)$ and the Rotalipora subticinensis Zone of Caron (1985).

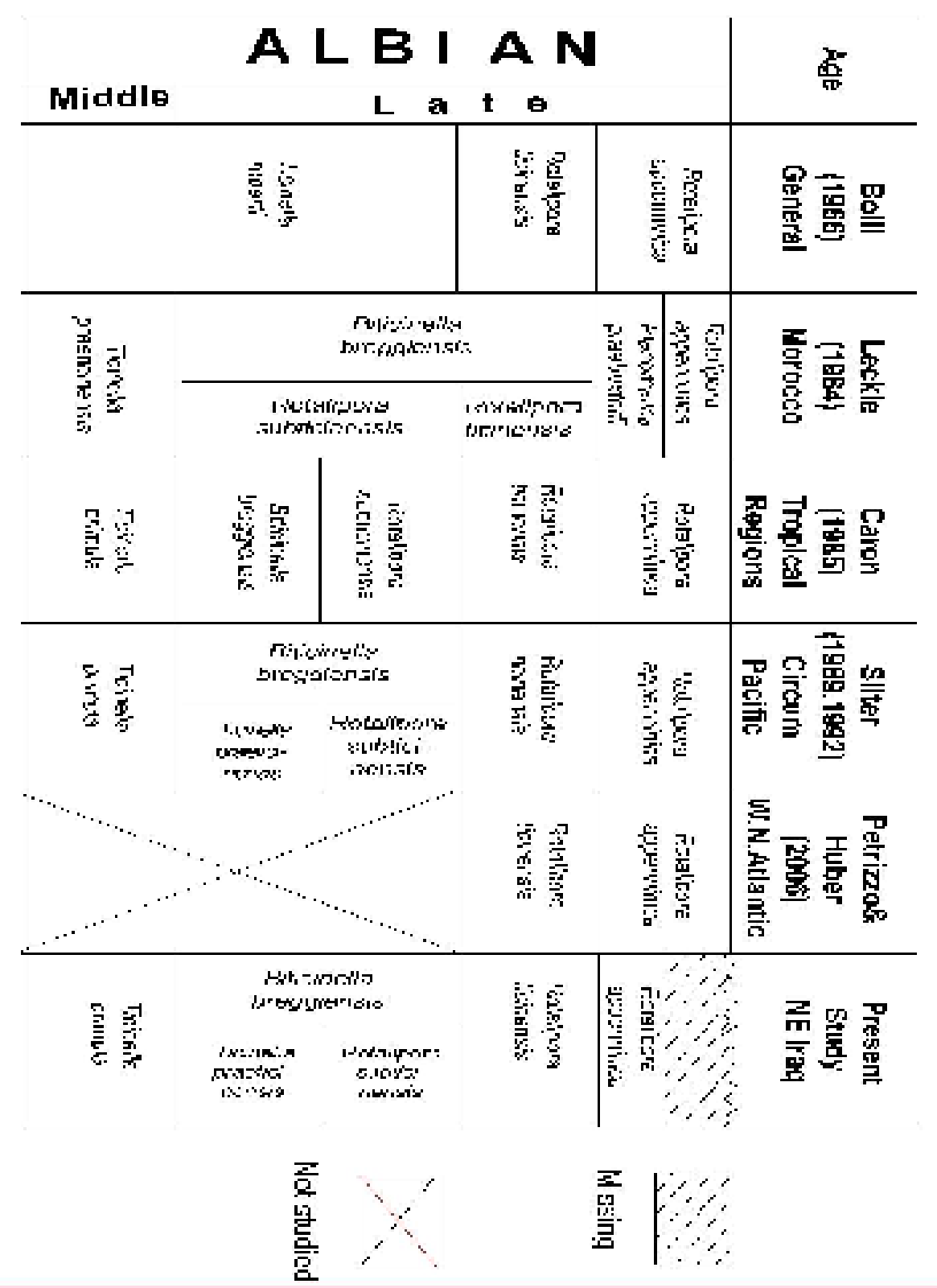

Fig. 3: Correlation of the zonal scheme of the studied sequence with those. proposed by some authors. 


\section{Rotalipora ticinensis Interval Zone}

Definition : Interval from the first occurrence of Rotalipora ticinensis ( Gandolfi) to the initial appearance of Rotalipora appenninica ( Renz).

Boundaries : The base of the zone is marked by the first appearance of the zonal marker, while the top of the zone is placed at the horizon of the first appearance of Rotalipora appenninica ( Renz ).

Thickness: $82.7 \mathrm{~m}$.

Correlation :The present zone is correlative to the Rotalipora ticinensis Zone of Caron $(1985)$ and Sliter $(1989,1992)$ which is assigned to Late Albian .

\section{Rotalipora appenninica Interval Zone ( part )}

Definition : Interval from the first occurrence of Rotalipora appenninica ( Renz) to the first appearance of Rotalipora brotzeni (Sigal).

Boundaries: The base of the zone is marked by the first appearance of the zonal marker . The Rotalipora appenninica Zone is represented in the study area only with the lower part, while the upper part of the zone is missing. However the upper boundary of this zone is placed at the first occurrence of Rotalipora brotzeni (Sigal) (Caron 1985 and Sliter 1989,1992).

Thickness : $18.6 \mathrm{~m}$.

Correlation : As it is defined here the present zone is equivalent to the lower part of the Rotalipora appenninica Zone of Caron (1985) and Sliter (1989,1992) of latest Albian age.

\section{CONCLUSIONS}

1- The Balambo Formation in Jebel Azmer-Sulaimaniya area, northeastern Iraq, is 224 $\mathrm{m}$. thick and consists of well bedded hard limestone ranges from light yellow to light grey in colour. Black rich in organic matter limestone layers of $20-40 \mathrm{~cm}$ thick are interbedded randomly with the yellow limestone.

2- The identified cosmopolitan foraminifera from the 92 samples show typical Tethyan characters, and defined four foraminiferal interval zones and two subzones. These are:

Rotalipora appenninica Zone

Rotalipora ticinensis Zone

Biticinella breggiensis Zone

Rotalipora subticinensis Subzone

Ticinella praeticinensis Subzone

Ticinella primula Zone

3- The presence of a major hiatus at the end of the Rotalipora appenninica Zone between the Albian and the Cenomanian delineates the upper boundary of the Balambo Formation with the Dokan Formation which is evident by the occurrence of Rotalipora cushmani (Morrow) at the base of Dokan Formation that indicates MiddleLate Cenomanian age. 


\section{REFERENCES}

Bellen, R.C.Van; Dunnington, H.V.; Wetzel, R.; and Morton, D., 1959, Lexique Stratigraphique International . Asie, Iraq, 3(10a), 333p.

Bolli, H. M., 1966, Zonation of Cretaceous to Pliocene marine sediments based on planktonic foraminifera. Boletin Informativo Asociacion Venezolana de Geologia, Mineria y Petroleo, 9, pp.3-32.

Buday, T., 1980, Stratigraphy and Paleogeography, In: Kassab, I.I.M. and Jassim, S.Z. (eds.) : The regional geology of Iraq. SOM (D.G.Geol.Sur.Min.Invest.) Baghdad ,v.1, 445P.

Caron, M., 1985, Cretaceous planktic foraminifera, In : Bolli, H.M., Saunders, J.R. and Perch-Nielsen, K. (eds.) : Plankton stratigraphy. Cambridge Univ.Press, pp.17-86.

Dunham, R.J., 1962, Classification of carbonate rocks according to depositional texture, In : Ham, W.E. (ed.) Classification of carbonate rocks. Amer. Ass. Petrol. Geol. Bull., 1, pp. 108-121.

Leckie, R.M., 1984, Mid- Cretaceous planktonic foraminiferal biostratigraphy of Central Morocco, Deep Sea Drilling Project Leg 79, Sites 545 and 547. Initial Reports of the DSDP, 79, pp. 579-620.

Petrizzo, M.R. and Huber, B.,2006, Biostratigraphy and taxonomy of Late Albian planktonic foraminifera from ODP leg 171b (Western North Atlantic Ocean), Journal of Foraminiferal Research, Apr 2006; 36: pp. 166-190.

Radoicic, R., 1995, A contribution to the Cretaceous biostratigraphy of Kaolos Area, NE Iraq. Annales geologiques de la Peninsule Balkanique, vol. 59, no. 1, pp. 27-52.

Sliter, W.V. ,1989, Biostratigraphic zonation for the Cretaceous planktonic foraminifers examined in thin section . Jour. Foram. Res., vol. 19, no. 1, pp.1-19.

Sliter, W.V., 1992, Cretaceous planktonic foraminiferal biostratigraphy and paleoceanographic events in the Pacific Ocean with emphasis on indurated sediment. Centenary of Japanese Micropaleontology, pp. 281-299. 


\section{Plate 1}

1- Globigerinelloides bentonensis (Morrow), sample no.49, axial section, X70.

2- Rotalipora subticinensis (Gandolfi), sample no.49, axial section, X80.

3- Foraminiferal wackestone with Ticinella primula Luterbacher at bottom, equatorial section, Ticinella bejaouensis Sigal at top, equatorial section, sample no.1, X20.

4- Hedbergella simplex (Morrow), sample no.40, equatorial section, X70.

5- Hedbergella planispira (Tappan), sample no.75, equatorial section, X100.

6- Biticinella breggiensis (Gandolfi), sample no.67, axial section, X100.

7- Ticinella primula Luterbacher, samplel no.15, equatorial section, X90.

8- Ticinella praeticinensis Sigal, sample no.67, axial section, X100.

9- Rotalipora ticinensis (Gandolfi), sample no.90, axial section, X100.

10-Globigerinelloides ultramicra (Subbotina), sample no.49, axial section, $\mathrm{X} 100$.

11-Ticinella roberti (Gandolfi), sample no.83, equatorial section, X150.

12-Globigerinelloides ultramicra (Subbotina), sample no. 57, equatorial section, X60.

13-Rotalipora appenninica (Renz), sample no.89, axial section, X100.

14-Heterohelix moremani (Cushman), sample no.41, longitudinal section, X30. 
33 Iraqi Journal of Earth Sciences- Vol. 8- No 1- May- 2008

Plate 1
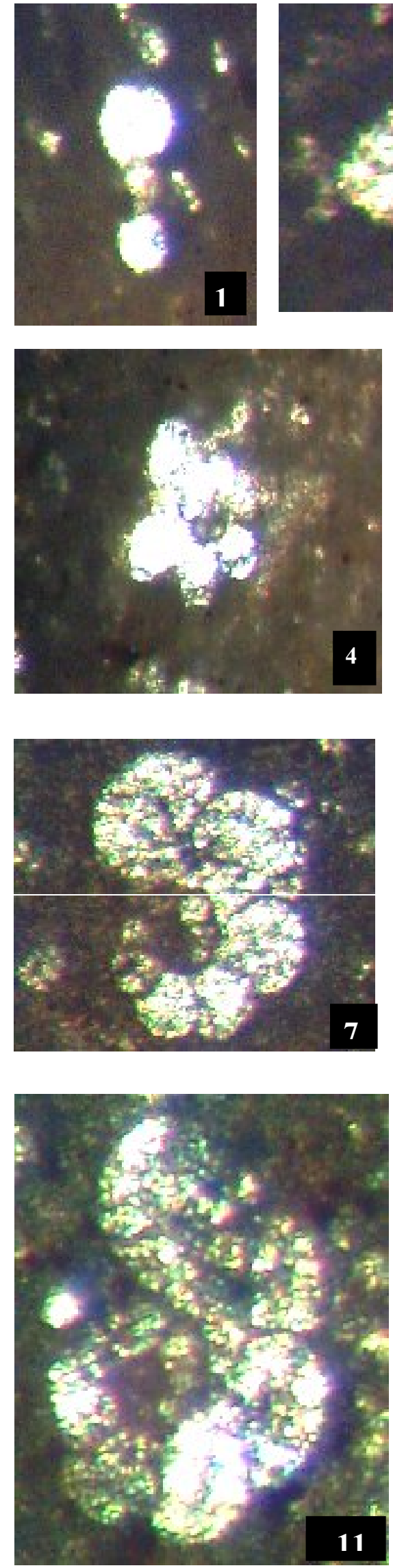
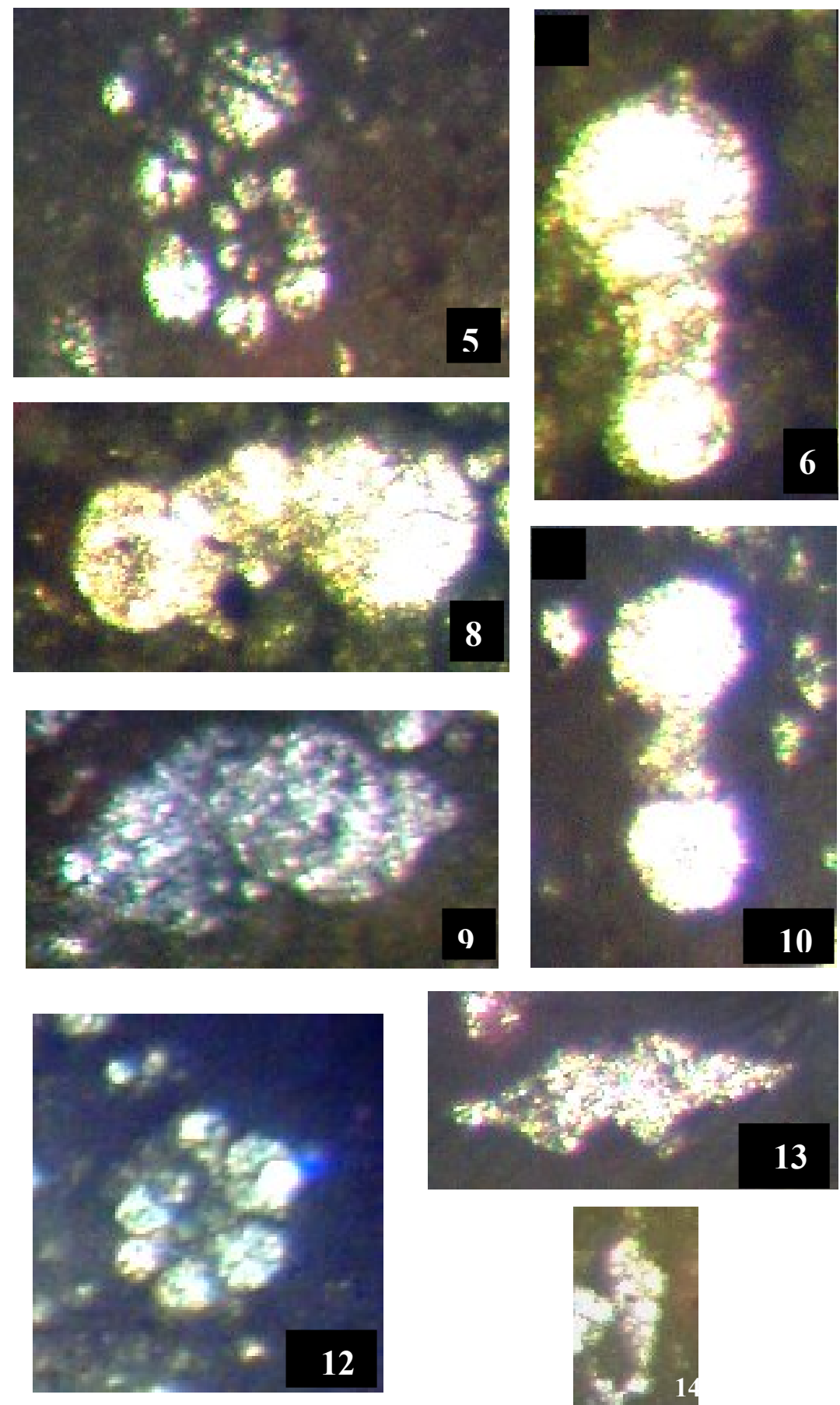